\title{
BIOCHEMICAL BEHAVIOR OF BEAN SEEDS AND GRAINS DURING STORAGE
}

\author{
COMPORTAMENTO BIOQUÍMICO DE SEMENTES E GRÃOS DE FEIJÃO \\ DURANTE O ARMAZENAMENTO
}

\author{
Flávia Danieli Rech CASSOL ${ }^{1}$; Andréa Maria Teixeira FORTES ${ }^{2}$; \\ Sílvia Renata Machado COELHO ${ }^{2}$; Ariane SPIASSI ${ }^{3}$; Nayara Parisoto BOIAGO'; \\ Lorena Camargo de MENDONÇA ${ }^{4}$; Camila Vanessa BUTURI ${ }^{5}$; Daiane Maria PILATTI ${ }^{6}$ \\ 1. Doutoranda em Engenharia Agrícola pela Universidade Estadual do Oeste do Paraná - UNIOESTE, Cascavel, PR, Brasil. \\ fdrcassol@yahoo.com.br; 2. Professora Doutora associada - UNIOESTE, Cascavel, PR, Brasil; 3. Doutora em Engenharia Agrícola - \\ UNIOESTE, Cascavel, PR, Brasil.; 4. Mestra em Engenharia Agrícola - UNIOESTE, Cascavel, PR, Brasil; 5. Mestra em Conservação e \\ Manejo de Recursos Naturais- UNIOESTE, Cascavel, PR, Brasil; 6. Doutoranda em Ecologia e Conservação, Universidade Federal do \\ Paraná, Curitiba, PR, Brasil.
}

\begin{abstract}
The development of researches about vigor provides greater insight about the physiological behavior of seeds over storage periods. The aim of this study was to evaluate the biochemical changes which occurred in beans stored for 360 days. Analyses were performed at 0, 30, 90, 180, 270, and 360 days after receiving the seeds (S1 and S2) and grains (G1 and G2) of BRS Splendor. The following tests were conducted: water content, electrical conductivity, and chemical composition of the soaking solution, where sugars and ions $\mathrm{Fe}^{2+}, \mathrm{Zn}, \mathrm{Ca}^{2+}, \mathrm{Mg}^{2+}$ and $\mathrm{K}^{+}$were quantified. The experimental design was completely randomized split-plot and means were compared through Tukey test $(\mathrm{p}>0.05)$. Water content decreased after 90 days, and after 180 days reached an average of $16 \%$. The electrical conductivity showed the greatest loss of solute after 90 days. Larger amounts of soluble sugars were found in S1 and G1. The quantities of potassium and calcium decreased after 360 days, while magnesium increased after 90 days of storage. The electrical conductivity test showed no direct relation to the quantification of the investigated ions. The amount and behavior of amino acids and studied ions did not showed relation to the decrease in vigor of beans.
\end{abstract}

PALAVRAS-CHAVE: Phaseolus vulgaris L. Vigor. Electrical conductivity. Electrolytes leaching.

\section{INTRODUCTION}

The global increase in food demand establishes a need to make better use of cultivable lands. For this purpose, it is necessary to use certified seeds, in order to increase crop productivity. Seeds such as bean (Phaseolus vulgaris L.), one of the most consumed grains in Brazil, that when combined with rice provides a balanced diet, with proteins, carbohydrates, minerals, fibres, vitamins and amino acids (RIGUEIRA et al., 2009).

Quality control programs seek to evaluate seed physiological potential, in order to set a direct relationship between seed vigor and crop establishment, key attributes to agricultural development (COIMBRA et al., 2009). To that extent, usage of tests that are sensitive to biochemical alterations, during seed aging, becomes very relevant to estimate viability and storage potential (COSTA et al., 2007).

The beginning of the seed deterioration process can be indicated by the destruction of cell membranes system (SANTOS et al., 2005; COSTA et al., 2007). And it can be quantified through electric conductivity test. Vigorous seeds present a greater repairing capacity of damages in cell membranes. Therefore, during soaking, the electrolytic leaching is smaller (MARCOS FILHO, 2005; BINOTTI et al., 2008; COSTA et al., 2008).

The leached of the electrical conductivity test is composed, mainly, of sugars, amino acids and inorganic ions, such as potassium, calcium, magnesium, sodium and manganese. High concentrations - of the above substances - can be an indicative of vigor and germination loss (MARCOS FILHO, 2005; BINOTTI et al., 2008). Among the best studied electrolytes, to try establishing a correlation with physiological quality of seeds, are calcium, magnesium and potassium, which are researched by many authors (BINOTTI et al., 2008; COSTA et al., 2008; FESSEL et al., 2010; SILVA et al., 2012).

In face of the need for more information regarding fast and objective tests of vigor, and its relationship with seed longevity; this work aimed to evaluate the biochemical behavior of bean seeds and grains, and its relation to the physiological quality and longevity of beans during 360 days of storage, under natural conditions. 


\section{MATERIAL AND METHODS}

The tests were conducted using BRS Splendor beans ( $P$. vulgaris, black group), from the second harvest (dry) of 2011, cultivated in two farms of Cascavel city, field 1 ( $24^{\circ} 53^{\prime} 49.9^{\prime}$ ' $\mathrm{S}$ and $\left.53^{\circ} 31^{\prime} 36.1^{\prime \prime} \mathrm{W}\right)$ and field $2\left(24^{\circ} 49^{\prime} 36.0^{\prime} \prime \mathrm{S}\right.$ and $53^{\circ} 32$ ' 29.1' ' W), in western Paraná.

The fields were being used for seeds reproduction and only three meters around the area are marketed for consumption (grain), as established by Agriculture Ministry (BRASIL, 2011). Thereby, beans were classified as: field seeds 1 (S1), field seeds 2 (S2), field grains 1 (G1) and field grains 2 (G2).

Samples were separated and stored into paper Kraft bags, under non-controlled environmental conditions, for 360 days. Evaluations to determine biochemical quality were performed when samples arrived, and after $30 ; 90 ; 180 ; 270$ and 360 days of storage.

Water content was determined through standard oven method, at $105 \pm 3{ }^{\circ} \mathrm{C}$, for 24 hours, in accordance with methods indicated by Rules for Seeds Analyze - RAS (BRASIL, 2009).

Samples containing 50 beans were weighted and placed in a recipient containing $75 \mathrm{~mL}$ of deionized water, and kept at $25^{\circ} \mathrm{C}$ for 24 hours, afterwards, electrical conductivity reading was performed (VIEIRA; KRZYZANOWSKI, 1999).

Soluble sugar quantification was performed following Dubois (1956), $0.5 \mathrm{~mL}$ of aqueous solution of $5 \%$ phenol and $2.5 \mathrm{~mL}$ of concentrated sulphuric acid were added to $0.5 \mathrm{~mL}$ of the soaking water. The prepared was agitated and left to rest for 15 minutes. With samples colder, reading was performed in spectrophotometer at $490 \mathrm{~nm}$. The results were compared with glucose standard curve.

Iron $\left(\mathrm{Fe}^{2+}\right)$, Zinc $(\mathrm{Zn})$, Calcium $\left(\mathrm{Ca}^{2+}\right)$, Magnesium $\left(\mathrm{Mg}^{2+}\right)$ and Potassium $\left(\mathrm{K}^{+}\right)$ions were determined from the soaking water, through direct reading in flame atomic absorption spectrophotometer (BINOTTI et al., 2008).

A completely randomized split-plot design was used (CRD), containing four replications. The results were submitted to analysis of variance, average comparison test and regression analysis through Tukey $(\mathrm{p}>0,05)$, software $\mathrm{R}$, version 2.15.1 (R DEVELOPMENT CORE TEAM, 2011).

\section{RESULTS AND DISCUSSION}

A decrease in water content was observed after 90 days of storage. Hydration of beans was noticed after 180 days of storage, resulting in average values of $16 \%$ on water content, by the end of the experiment. In this study, oscillation of water content in relation to relative humidity modifications of storage period was observed, showing this water vapor exchange capacity to reach hygroscopic balance. These variations may be responsible for the behavior of the variables described below.

Table 1. Electrical conductivity of beans, from Splendor BRS variety, during storage periods.

Electrical conductivy $\left(\mu \mathrm{S} . \mathrm{cm}^{-1} \mathrm{~g}^{-1}\right)$

\begin{tabular}{lrrrrrr} 
Beans & \multicolumn{5}{c}{ Storage periods (days) } \\
\cline { 2 - 7 } S1 & 0 & 30 & 90 & 180 & 270 & \multicolumn{1}{c}{360} \\
S2 & $104.72 \mathrm{aAB}$ & $98.19 \mathrm{aCD}$ & $113.28 \mathrm{aA}$ & $91.69 \mathrm{aD}$ & $110.34 \mathrm{aBC}$ & $106.67 \mathrm{aAB}$ \\
$\mathrm{G} 1$ & $98.01 \mathrm{bAB}$ & $82.13 \mathrm{bCD}$ & $100.39 \mathrm{bA}$ & $79.18 \mathrm{bD}$ & $86.55 \mathrm{bBC}$ & $91.70 \mathrm{bAB}$ \\
$\mathrm{G} 2$ & $118.06 \mathrm{aAB}$ & $102.30 \mathrm{aCD}$ & $118.23 \mathrm{aA}$ & $92.68 \mathrm{aD}$ & $101.45 \mathrm{aBC}$ & $114.89 \mathrm{aAB}$ \\
$\mathrm{H}$ & $92.79 \mathrm{bAB}$ & $81.96 \mathrm{bCD}$ & $98.77 \mathrm{bA}$ & $79.22 \mathrm{bD}$ & $86.97 \mathrm{bBC}$ & $103.31 \mathrm{bAB}$ \\
\hline
\end{tabular}

Means followed by case letter: comparison between columns and rows differ between them by Tukey test (5\% of significance). S1 and G1 seeds and grains from field 1, S2 and G2 seeds and grains from field 2, respectively.

After 90 days of storage the biggest electrolytic leaching was observed, and after 180 days, the smaller one (Table 1). However, variation in electrical conductivity values, over the experiment, indicates that the test wasn't sensitive enough to detect a decrease in beans vigor, corroborating with Silva et al. (2012), who studied beans of high vigor; with Fessel et al. (2010) who tested soy seeds stored at 10 and $20^{\circ} \mathrm{C}$, and finally with Soares et al. (2010), using sorghum seeds.
However, the test was effective to distinguish beans vigor in Santos et al. (2005) work, and also to batches of beans studied by Cassol et al. (2012), during storage for eight and three months, respectively. The same test efficiency, to evaluate physiological quality, was proven by Coimbra et al. (2009) when testing sweet corn seeds, and by Braz and Rossetto (2009) regarding sunflower. 


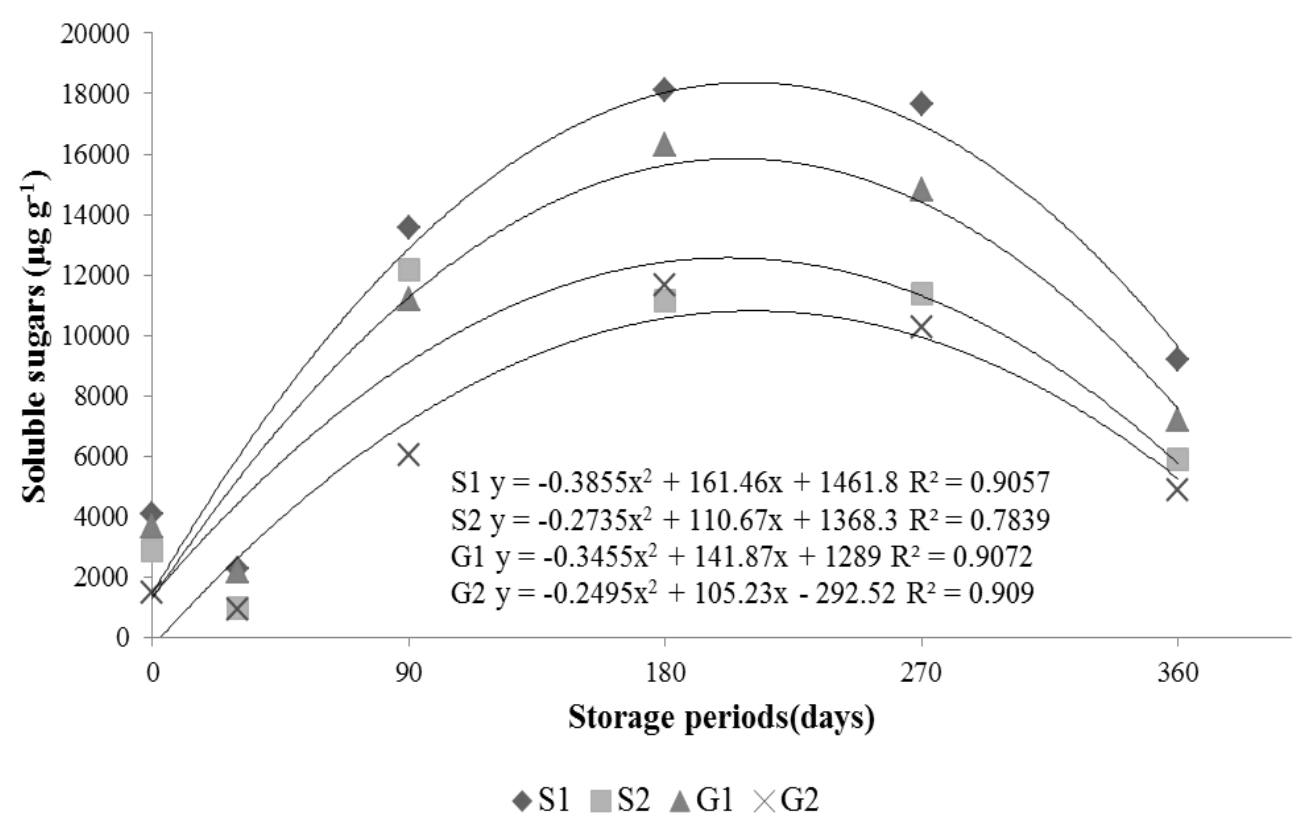

Figure 1. Significant regression model to soluble sugars content of beans, from Splendor BRS variety, during storage periods. S1 and G1 seeds and grains from field 1, S2 and G2 seeds and grains from field 2, respectively.

It can be seen, on figure 1, on average the biggest amount of soluble sugars is showed in beans of field 1 , and the lowest averages are observed to G2. Lower values of this parameter were checked by Binotti et al. (2008), in their initial analysis, beans of Pearl cultivar. Being that, for this variable there was no significant interaction among factors. Similarly the beans, showed decrease after 30 days, following by increase after 180 days and a new drop of sugar levels.

These results differ from those obtained by Henning et al. (2010), which verified that vigorous seeds usually show great quantities of soluble sugars. In this matter, Marcos Filho (2005) states that during seeds deterioration, a decreasing of the sugars levels can be observed. The decline of this variable suggests the start of the deterioration process. This variation was inversely proportional to the water content, indicating an increase on basal metabolic rate. Water content increase may stimulate respiratory process, mobilization of reserves and energy release, stimulating the deterioration.

During the present study, there was some variation on iron content. For $\mathrm{S} 1$, the presence of $\mathrm{Fe}$ was not quantified at the last analysis. Obtained values remained between 0.000 and 1.029 to $\mathrm{S} 1$, 0.034 and 0.784 for $\mathrm{S} 2,0.357$ and 0.798 for $\mathrm{G} 1$ and 0.062 and $0.889 \mu \mathrm{g} \mathrm{g}^{-1}$, for G2. These results were lowers than the ones found by Pereira et al. (2011), while studying creole beans in two years of cultivation, which obtained Fe variation between 62 to $161.7 \mathrm{mg} \mathrm{kg}^{-1}$. Also Mesquita et al. (2007) found greater quantities of this ion, 71.37 to $126.9 \mathrm{mg} \mathrm{kg}^{-1}$, while investigating different beans lineages.

There was a reduction on zinc quantities (Table 2) until 270 days of storage, with a slight increase at the last analysis. Superior values were obtained by Pereira et al. (2011), between 32 a 68 $\mathrm{mg} \mathrm{kg}^{-1}$, when they evaluated two years of creole beans growth, while Binotti et al. (2008) didn't found any $\mathrm{Fe}$ or $\mathrm{Zn}$ in the electrical conductivity water of their experiment.

The beans presented similar behavior over the course of the research, regarding calcium quantities (Table 2). Values obtained in this work are lower than the ones obtained by Mesquita et al. (2007) (0.30 to $2.8 \mathrm{~g} \mathrm{~kg}^{-1}$ ) when studying different beans lineages, and Pereira et al. (2011) (0.25 to $0.95 \mathrm{~g} \mathrm{~kg}^{-1}$ ), featuring creole beans genotypes, whereas the present values are higher than the ones described by Binotti et al. (2008), $0.012 \mathrm{mg} \mathrm{g}^{-1}$, at the first analysis of Pearl Beans.

According to Costa et al. (2008), calcium atomic radius is bigger than potassium and magnesium; this characteristic may have hampered calcium transposition through the membranes, in such way that they couldn't detect the presence of $\mathrm{Ca}$ in their trial using pea.

Once the interference of the atomic radius has been acknowledged, this may explain why $\mathrm{Ca}$, $\mathrm{Fe}$ and $\mathrm{Zn}$ quantities were so low, since they have the biggest atomic radius between the studied ions of this work. 
Table 2. Quantities of ions zinc, calcium and magnesium measured through the soaking water of beans, from Splendor BRS variety, during storage periods.

\begin{tabular}{|c|c|c|c|c|c|c|}
\hline \multirow{3}{*}{ Beans } & \multicolumn{6}{|c|}{ Zinc $\left(\mu \mathrm{g} \mathrm{g}^{-1}\right)$} \\
\hline & \multicolumn{6}{|c|}{ Storage periods (days) } \\
\hline & 0 & 30 & 90 & 180 & 270 & 360 \\
\hline S1 & $47.614 \mathrm{aA}$ & $51.624 \mathrm{bAB}$ & $49.350 \mathrm{aB}$ & $39.581 \mathrm{aB}$ & $23.478 \mathrm{aB}$ & $29.250 \mathrm{bB}$ \\
\hline $\mathrm{S} 2$ & $48.022 \mathrm{abA}$ & $54.378 \mathrm{bB}$ & $48.704 \mathrm{aB}$ & $35.136 \mathrm{aB}$ & $25.256 \mathrm{aB}$ & $29.686 \mathrm{bB}$ \\
\hline G1 & $39.244 \mathrm{bBC}$ & $40.661 \mathrm{aA}$ & 51.783aABC & $32.642 \mathrm{aBC}$ & $20.586 \mathrm{aC}$ & $25.670 \mathrm{aAB}$ \\
\hline $\mathrm{G} 2$ & \multicolumn{6}{|c|}{ Calcium $\left(\mu \mathrm{g} \mathrm{g}^{-1}\right)$} \\
\hline S1 & $8.711 \mathrm{abAB}$ & $6.135 \mathrm{abA}$ & $5.551 \mathrm{aAB}$ & $5.316 \mathrm{aBC}$ & 4.215aD & $4.292 \mathrm{abC}$ \\
\hline S2 & 7.959abA & $5.001 \mathrm{aA}$ & $5.962 \mathrm{aA}$ & $3.682 \mathrm{aB}$ & $3.194 \mathrm{aC}$ & $3.530 \mathrm{abB}$ \\
\hline G1 & $8.486 \mathrm{bBC}$ & $7.902 \mathrm{bAB}$ & $6.067 \mathrm{aA}$ & 5.292aCD & $4.396 \mathrm{aE}$ & $6.751 \mathrm{bDE}$ \\
\hline G2 & \multicolumn{5}{|c|}{ Magnesium $\left(\mu \mathrm{g} \mathrm{g}^{-1}\right)$} & $7.667 \mathrm{aB}$ \\
\hline S1 & $9.968 \mathrm{aD}$ & $9.583 \mathrm{aD}$ & $10.244 \mathrm{aD}$ & $497.667 \mathrm{bC}$ & $2571.638 \mathrm{aB}$ & $4574.044 \mathrm{aA}$ \\
\hline S2 & $9.143 \mathrm{aD}$ & $8.828 \mathrm{aD}$ & $9.404 \mathrm{aD}$ & $491.462 b C$ & $2416.378 \mathrm{aB}$ & $4414.543 \mathrm{aA}$ \\
\hline G1 & $8.985 \mathrm{aD}$ & $8.631 \mathrm{aD}$ & $9.271 \mathrm{aD}$ & $618.063 \mathrm{aC}$ & $2203.513 a B$ & $4192.276 \mathrm{aA}$ \\
\hline $\mathrm{G} 2$ & $9.280 \mathrm{aD}$ & $8.789 \mathrm{aD}$ & $9.445 \mathrm{aD}$ & $616.374 \mathrm{aC}$ & $2383.182 \mathrm{aB}$ & $4372.079 \mathrm{aA}$ \\
\hline
\end{tabular}

Means followed by the same capital letter in the column and small letter in the line are not different according to (Tukey test, $\mathrm{p} \geq$ $0.05 \%$ ). S1 and G: seeds and grains from field 1; S2 and G2: seeds and grains from field 2.

Vanzolini \& Nakagawa (2003) couldn't establish a connection between calcium leaching and physiological potential of peanut. Also, different lots of onions showed a decrease of calcium during a study carried out by Costa et al. (2007). Similar results were found by the present study, which wasn't able to use this variable $(\mathrm{Ca})$ when analyzing seeds vigor. Whereas calcium increase was documented by Fessel et al. (2006) for corn, by Fessel et al. (2010) for soy seeds with high and low vigor, and by Silva et al. (2012) in lots of beans with lower physiological quality.

After 90 days of storage, a little amount of magnesium was found in the soaking water of beans (Table 2). Seeds and grains showed statistical differences after 180 days of storage, when grains released more magnesium than seeds. These values are higher than the ones obtained by Pereira et al. (2011), between 0.89 and $2.79 \mathrm{mg} \mathrm{kg}^{-1}$, for creole beans.

These results disagree with the ones obtained by Costa et al. (2008), when testing pea seeds submitted to pre-hydration, it was possible to distinguish inferior lots using this parameter. Nevertheless, Vanzolini and Nakagawa (2003), analyzing the same test for peanut seeds were not able to distinguish amounts of $\mathrm{Mg}^{2+}$ of their lots, while Costa et al. (2007), studying the relationship between magnesium and physiological potential in onion seeds, noticed a downfall of this parameter during their work.

The present study discovered an increase of $\mathrm{Mg}^{2+}$ during storage periods, this result is also confirmed by Fessel et al. (2006), which tested corn seeds storage under higher temperatures, by Fessel et al. (2010) using soy seeds under the previous conditions and by Silva et al. (2012), which tested beans seeds of lower physiological quality. Alterations caused by deterioration modify the chemical composition of seeds, possibly causing magnesium increase, a less soluble ion (MARCOS FILHO, 2005).

Potassium quantities (Figure 2) showed a decrease after 90 days, followed by a discrete increase after 360 days of storage. But, according to Custódio and Marcos Filho apud Marcos Filho (2005), potassium release is directly related to the cell membranes permeability.

This greater permeability, as a rule, is related to a bigger deterioration. Kikuti et al. (2008) and Binotti et al. (2008) found a strong correlation between great release of $\mathrm{K}^{+}$and lower physiological quality of beans and peanut seeds. Different authors have been stated that potassium is the most released ion by seeds (VANZOLINI; NAKAGAWA, 2003; MARCOS FILHO, 2005; FESSEL et al., 2006; COSTA et al., 2008; FESSEL et al., 2010; SILVA et al., 2012). The results were higher than the ones observed by Binotti et al. (2008), for pearl beans $\left(0.17 \mathrm{mg} \mathrm{g}^{-1}\right)$, and by Pereira et al. (2011), for creole beans in two years of cultivation (10.92 to $20.21 \mathrm{mg}$ $\left.\mathrm{kg}^{-1}\right)$. The increase of $\mathrm{K}+$ concentration, in the water where seeds were immersed, is inversely related to the germination potential and seeds vigor, possibly being a rapid and indirect way to determine vigor, according to Binotti et al. (2008). 


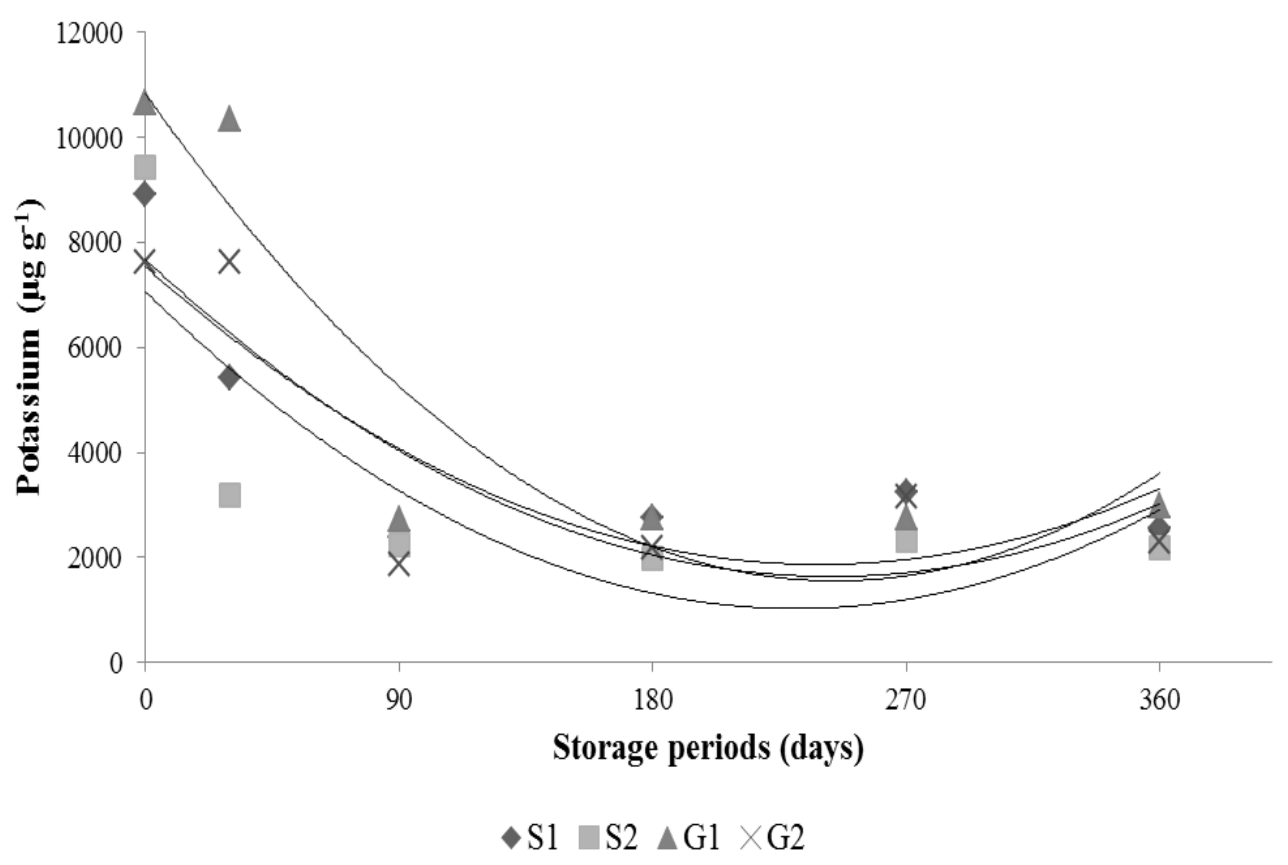

Figure 2. Potassium amount data of beans, from Splendor BRS variety, during storage periods. S1 and G1 seeds and grains from field 1, S2 and G2 seeds and grains from field 2, respectively.

In the meantime Fessel et al. (2006) noticed that the decrease in the corn seeds vigor was directly proportional to the loss of potassium through the damaged membrane, corroborating Vanzolini \& Nakagawa (2003) for peanut seeds, Costa et al. (2008) for pea seeds, Fessel et al. (2010) for soy seeds and Silva et al. (2012) for bean seeds.

By relating the present results with the germination tests performed by Cassol et al. (2016), we can notice that beans from field 1 demonstrated, after 360 days of storage, a lower germination potential. At the same time, they showed greater quantities of potassium release in the electrical conductivity water, even though this relation didn't show the same tendencies during tests. So it isn't possible to associate $\mathrm{K}^{+}$amounts with beans vigor loss. Thus we assume that the relationship between the quality of storage seeds and grains and the biochemical behavior is not well established yet, requiring further studies.

Over the course of this research we conclude that it was possible to verify that the variation of the electrical conductivity values didn't show any correspondent relation with the quantification of the investigated ions, indicating that this test wasn't efficient to detect beans vigor decrease, in a way that the amount and behavior of soluble sugars and ions, during storage, didn't allow the correlation between these variables with beans vigor downfall.

\section{CONCLUSIONS}

Beans seeds and grains evaluated showed ions modifications, during 360 days of storage, under natural conditions.

The behavior of these parameters, under conditions which the test was performed, was not efficient enough to relate it with the physiological quality and longevity of the BRS Splendor variety.

\section{ACKNOWLEDGMENTS}

The authors would like to acknowledge Coordination for higher Education Staff Development (CAPES) for their financial support during the execution of this research.

RESUMO: O desenvolvimento de pesquisas sobre vigor proporciona maior conhecimento sobre o comportamento fisiológico das sementes ao longo do armazenamento. O objetivo desse estudo foi avaliar as mudanças bioquímicas ocorridas em feijões armazenados por 360 dias. As análises foram realizadas aos 0, 30, 90, 180, 270 e 360 dias, após o recebimento das sementes e grãos da cultivar BRS Esplendor. Foram realizados os testes de teor de água, condutividade elétrica, e a composição química da solução de embebição, onde os teores de açúcares e íons $\mathrm{Fe}^{2+}, \mathrm{Zn}^{2}, \mathrm{Ca}^{2+}$, $\mathrm{Mg}^{2+}$ e $\mathrm{K}^{+}$foram quantificados. $\mathrm{O}$ delineamento foi inteiramente casualizado em esquema de parcelas subdivididas e as 
médias comparadas pelo teste de Tukey ( $\mathrm{p}>0,05)$. A condutividade elétrica apresentou maior perda de solutos aos 90 dias. As quantidades de potássio e cálcio diminuíram até os 360 dias, enquanto o magnésio teve aumento após 90 dias de armazenamento. O teste de condutividade elétrica não apresentou relação direta com a quantificação dos íons investigados. A quantidade e o comportamento dos aminoácidos e dos íons estudados não demonstraram relação com a queda do vigor dos feijões.

PALAVRAS-CHAVE: Phaseolus vulgaris L. Vigor condutividade elétrica. Lixiviação de eletrólitos.

\section{REFERENCES}

BINOTTI, F. F. S.; HAGA, K. I.; CARDOSO, E. D.; ALVES, C. Z.; SÁ, M. E.; ARF, O. Efeito do período de envelhecimento acelerado no teste de condutividade elétrica e na qualidade fisiológica de sementes de feijão. Acta Scientiarum Agronomy, Maringá, v. 30, n. 2, p. 247-254, 2008.

http://dx.doi.org/10.4025/actasciagron.v30i2.1736

BRASIL - Ministério da Agricultura, Pecuária e Abastecimento. Regras para análise de sementes. Brasília: MAPA/ACS, 2009. 399p. Disponível em:

http://www.agricultura.gov.br/arq_editor/file/2946_regras_analise_sementes.pdf. Acesso em: 25 abr. 2011.

BRASIL - Ministério da Agricultura, Pecuária e Abastecimento. Guia de Inspeção de Campos para

Produção de Sementes, $3^{\text {ed }}$. Brasília: Mapa/ACS, 2011. 41p. Disponível em:

http://www.agricultura.gov.br/arq_editor/file/3494_guia_de_inspecao_sementes.pdf. Acesso em: 15 mai. 2011.

BRAZ, M. R.S.; ROSSETTO, C. A. V. Correlação entre testes para avaliação da qualidade de sementes de girassol e emergência das plântulas em campo. Ciência Rural, Santa Maria, v. 39, n. 7, p. 2004-2009, 2009. http://dx.doi.org/10.1590/S0103-84782009005000146

CASSOL, F. D. R.; FORTES, A. M. T.; NUNES, J. V. D.; VEIT, M. R.; CRUZ, M. Qualidade fisiológica de lotes de sementes de feijão em função do armazenamento. Cultivando o Saber, Cascavel, v. 5, n. 2, p. 85-87, 2012.

CASSOL, F. D. R.; FORTES, A. M. T.; MENDONÇA, L. C. de; BUTURI, C. V.; MARCON, T. R.. Comportamento fisiológico de sementes e grãos de feijão durante o armazenamento. Anais da Academia Brasileira de Ciências, Rio de Janeiro, v. 88, n. 2, p. 1069-1077, 2016.

COIMBRA, R. A.; MARTINS, C. C.; TOMAZ, C. A.; NAKAGAWA, J. Testes de vigor utilizados na avaliação da qualidade fisiológica de lotes de sementes de milho-doce (sh2). Ciência Rural, Santa Maria, v. 39, n. 9, p. 2402-2408, 2009. http://dx.doi.org/10.1590/S0103-84782009000900004

COSTA, C.J.; VAHL, L.C.; VILLELA, F.A. Testes de lixiviação de íons inorgânicos e condutividade elétrica para avaliação do potencial fisiológico de sementes de cebola. Revista Brasileira de Agrociência, Pelotas, v. 13, n. 4, p. 449-453, 2007.

COSTA, C. J.; VILLELA, F. A.; BERTONCELLO, M. R.; TILLMANN, M. A.; MENEZES, N. L. Préhidratação de sementes de ervilha e sua interferência na avaliação do potencial fisiológico. Revista Brasileira de Sementes, Londrina, v. 30, n. 1, p. 198-207, 2008. http://dx.doi.org/10.1590/S0101-31222008000100025

DUBOIS, M.; GILLES, K.A.; HAMILTON, J. K.; REBERS, P. A.; SMITH, F. Colorimetric method for determination of sugars and related substances. Analytical Chemistry, v. 28, p. 350-356, 1956. http://dx.doi.org/10.1021/ac60111a017

FESSEL, A. S.; VIEIRA, R. D.; CRUZ, M. C. P.; PAULA, R. C.; PANOBIANCO, M. Electrical conductivity testing of corn seeds as influenced by temperature and period of storage. Pesquisa Agropecuária Brasileira, Brasília, v. 41, n. 10, p. 1551-1559, 2006. http://dx.doi.org/10.1590/S0100-204X2006001000013 
FESSEL, A. S.; PANOBIANCO, M.; SOUZA, C. R.; VIEIRA, R. D. Teste de condutividade elétrica em sementes de soja armazenadas sob diferentes temperaturas. Bragantia, Campinas, v. 69, n.1, p. 207-214, 2010. http://dx.doi.org/10.1590/S0006-87052010000100026

HENNING, F. A.; MERTZ, L. M.; JACOB JUNIOR, E. A.; MACHADO, R. D.; FISS, G.; ZIMMER, P. J. Composição química e mobilização de reservas em sementes de soja de alto e baixo vigor. Bragantia, Campinas, v. 69, n. 3, p. 727-734, 2010. http://dx.doi.org/10.1590/S0006-87052010000300026

KIKUTI, H.; MEDINA, P. F.; KIKUTI, A. L. P.; RAMOS, N. P. Teste de lixiviação de potássio para avaliação do vigor de sementes de amendoim. Revista Brasileira de Sementes, Londrina, v. 30, n. 1, p.10-18, 2008. http://dx.doi.org/10.1590/S0101-31222008000100002

MARCOS FILHO, J. Fisiologia de Sementes de plantas cultivadas. Piracicaba: Fealq, 2005. 495p.

MESQUITA, F. R.; CORRÊA, A. D.; ABREU, C. M. P.; LIMA, R. A. Z.; ABREU, A. F. B. Linhagens de feijão (Phaseolus vulgaris L.): composição química e digestibilidade proteica. Ciência e Agrotecnologia, Lavras, v. 31, n. 1, p. 1114-1121, 2007.

PEREIRA, T.; COELHO, C. M. M.; SANTOS, J. C. P. dos; BOGO, A.; MIQUELLUTI, D. J. Diversidade no teor de nutrientes em grãos de feijão crioulo no Estado de Santa Catarina. Acta Scientiarum Agronomy, Maringá, v. 33, n. 3, p. 477-485, 2011.

R DEVELOPMENT CORE TEAM. R: A language and environment for statistical computing. R Foundation for Statistical Computing; Vienna; Austria, 2011. Disponível em: http://www.R-project.org/. Acesso em: 12 ago. 2012.

RESENDE, O.; CORRÊA, P. C.; FARONI, L. R. D’A.; CECON, P. R. Avaliação da qualidade tecnológica do feijão durante o armazenamento. Ciência e Agrotecnologia, Lavras, v. 32, n. 2, p. 517-524, 2008.

RIGUEIRA, R. J. A.; LACERDA FILHO, A. F.; VOLK, M. B. Avaliação da qualidade do feijão armazenado em ambiente refrigerado. Revista Alimentos e Nutrição, Araraquara, v. 20, n. 4, p. 649-655, 2009.

SANTOS, C. M. R.; MENEZES, N. L.; VILLELA, F. A. Modificações fisiológicas e bioquímicas em sementes de feijão no armazenamento. Revista Brasileira de Sementes, Londrina, v. 27, n. 1, p. 104-114, 2005. http://dx.doi.org/10.1590/s0101-31222005000100013

SILVA, C. D.; PAZETO, M. S. R.; VIEIRA, R. D. Electrical conductivity and mineral composition of the Imbibition solution of bean seeds during storage. Ciência e Agrotecnologia, Lavras, v. 36, n. 2, p. 147-155, 2012.

SOARES, M. M.; CONCEIÇÃO, P. M.; DIAS, D. C. F. S.; ALVARENGA, E. M. Testes para avaliação do vigor de sementes sorgo com ênfase à condutividade elétrica. Ciência e Agrotecnologia, Lavras, v. 34, n. 2, p. 391-397, 2010.

VANZOLINI, S.; NAKAGAWA, J. Lixiviação de potássio na avaliação da qualidade Fisiológica de sementes de amendoim. Revista Brasileira de Sementes, Londrina, v. 25, n. 2, p. 7-12, 2003.

http://dx.doi.org/10.1590/S0101-31222003000400002

VIEIRA, R. D.; KRZYZANOWSKI, F. C. Teste de condutividade elétrica. In: KRZYZANOWSKI, F. C.; VIEIRA, R. D.; FRANÇA NETO, J. B. (Eds.) Vigor de sementes: conceitos e testes. Londrina: ABRATES, 1999. p. 68-93. 